\title{
Hypocomplementemic urticarial vasculitis complicated with diffuse alveolar hemorrhage: a case report and review of literature
}

\author{
Paola Gnerre, ${ }^{1}$ Sandra Buscaglia, ${ }^{1}$ Alessandro Cattana, ${ }^{1}$ Andrea Pestarino, ${ }^{2}$ Silvia Ardoino, ${ }^{3}$ \\ Ezio Venturino, ${ }^{3}$ Lionello Parodi ${ }^{1}$ \\ ${ }^{1}$ Department of Internal Medicine, San Paolo Hospital, Savona; ${ }^{2}$ Department of Dermatology, San Paolo Hospital, Savona; \\ ${ }^{3}$ Department of Pathology, San Paolo Hospital, Savona, Italy
}

\begin{abstract}
Urticarial vasculitis is a small-vessel vasculitis characterized clinically by urticaria and microscopically by leukocytoclastic vasculitis. Hypocomplementemic urticarial vasculitis syndrome is a rare subtype of urticarial vasculitis with organ involvement and persistent, acquired hypocomplementemia. Pulmonary involvement, usually seen as diffuse alveolar damage, is an uncommon complication and a significant cause of morbidity and mortality. Here we present a rare case of hypocomplementemic urticarial vasculitis syndrome complicated by diffuse alveolar damage and describe the beneficial effect of cyclophosphamide-dexamethasone.
\end{abstract}

\section{Introduction}

Urticarial vasculitis (UV) is an immune complexmediated vasculitis characterized by recurrent episodes of urticaria with evidence of leukocytoclastic vasculitis. ${ }^{1}$ The lesions typically persist for more than $24 \mathrm{~h}$ and resolve with residual hyperpigmentation. Hypocomplementemic urticarial vasculitis syndrome (HUVS) is an uncommon, distinct subtype of urticarial vasculitis with multiorgan involvement. ${ }^{2}$ To make a diagnosis of HUVS, the typical cutaneous efflorescences must be accompanied by decreased complement levels. All HUVS patients exhibit extremely low levels of C1q. ${ }^{3}$ The etiology and link with other conditions such as infection, malignancy, certain drugs and connective tissue dis-

Correspondence: Paola Gnerre, Department of Internal Medicine, San Paolo Hospital, via Genova I, 17100 Savona, Italy. Tel.: +39.019.8404358 - Fax: +39.019.8404583.

E-mail: pgnerre@yahoo.it

Key words: hypocomplementemic urticarial vasculitis, leukocytoclastic vasculitis, diffuse alveolar hemorrhage.

Conflict of interests: the authors declare that they have no potential conflict of interests. The patient gave his informed consent to the publication of this case report.

Received for publication: 12 March 2013.

Revision received: 7 May 2013.

Accepted for publication: 27 May 2013.

This work is licensed under a Creative Commons Attribution NonCommercial 3.0 License (CC BY-NC 3.0).

C Copyright P. Gnerre et al., 2014

Licensee PAGEPress, Italy

Italian Journal of Medicine 2014; 8:44-50

doi:10.4081/itjm.2014.155 eases, including systemic lupus erythematosus (SLE), are still unknown. ${ }^{4}$ The exact incidence and prevalence of HUVS are also unknown, as this is a rare and severe systemic form of UV. HUVS is present in 7 to $8 \%$ of patients with SLE and $54 \%$ of patients with HUVS are diagnosed as having SLE in their follow-up period. ${ }^{4}$ Patients with HUVS may have significant morbidity and mortality, most commonly caused by chronic obstructive pulmonary disease and acute laryngeal edema. ${ }^{2}$ One of the worst pulmonary complications is acute lung injury with a clinical presentation of acute respiratory distress syndrome. ${ }^{5}$ The classic histological manifestation of acute lung injury/acute respiratory distress syndrome is diffuse alveolar damage (DAH). DAH is a clinical entity characterized by hemoptysis, dyspnea, anemia and diffuse pulmonary infiltrations on chest radiography. ${ }^{5}$ Most cases of DAH have a pulmonary capillaritis usually seen in systemic autoimmune diseases, such as antineutrophil cytoplasmic antibody (ANCA)-associated vasculitis, systemic lupus erythematosus, rheumatoid arthritis and other systemic rheumatic diseases. ${ }^{6}$ Here we present a rare case of HUVS complicated by DAH and describe the excellent response to treatment with cyclophospamide and glucocorticoids. ${ }^{7}$ To the best of our knowledge, no previous cases of HUVS complicated by DAH have been published in the literature (Table 1). ${ }^{7-28}$

\section{Case Report}

A 58-year old female was referred to our department in March 2008 for persistent urticarial skin lesions which had started 11 months previously. She also reported suffering from arthralgia, deteriorating general health and recurrent conjunctivitis. She had a past history of a state of hypercoagulability (episodes of postoperative thrombosis in the upper legs). Physical 
Table 1. Hypocomplementemic urticarial vasculitis syndrome case reports.

\begin{tabular}{|c|c|c|c|c|c|}
\hline & Study & $\begin{array}{l}\text { Age (in years), } \\
\text { sex and date }\end{array}$ & $\begin{array}{c}\text { Case } \\
\text { presentation }\end{array}$ & Treatment & Organ involvement \\
\hline 1 & Current study & $58, \mathrm{~F}(2007)$ & 2013 & $\begin{array}{l}\text { Prednisone (variable dose), } \\
\text { cyclophosphamide } 100 \mathrm{mg} / \text { day } \\
\text { and mycophenolate mofetil ( } 2 \mathrm{~g} / \text { day) } \\
\text { No response to antihistamines, } \\
\text { cyclosporine } 200 \mathrm{mg} / \text { day, } \\
\text { azathioprine } 100 \mathrm{mg} \text { /day, dapsone } \\
100 \mathrm{mg} / \text { day, methotrexate } 7.5 \mathrm{mg} / \text { week }\end{array}$ & $\begin{array}{l}\text { Eyes (conjunctivitis), } \\
\text { kidneys (glomerular hematuria), } \\
\text { lungs (DAH), } \\
\text { joints (arthralgia) }\end{array}$ \\
\hline 2 & Agnello et al. ${ }^{8}$ & Not done & 1973 & Corticosteroids & $\begin{array}{l}\text { Joints (arthralgia), angioneurotic } \\
\text { edema }\end{array}$ \\
\hline 3 & McDuffie et al. ${ }^{9}$ & 4 patients & 1973 & Corticosteroids & Not known \\
\hline 4 & Oishi et al..$^{10}$ & $33, \mathrm{~F}$ & 1976 & Prednisolone & $\begin{array}{l}\text { Joints (arthralgia), } \\
\text { kidneys (nephropathy), } \\
\text { angioneurotic edema, eyes } \\
\text { (conjunctival injection) }\end{array}$ \\
\hline 5 & Zeiss et al. ${ }^{11}$ & 50, F (1975) & 1980 & $\begin{array}{l}\text { Prednisone (up to } 40 \mathrm{mg} / \text { day), } \\
\text { hydroxyazine, } \\
\text { azathioprine ( } 50 \text { to } 150 \mathrm{mg} / \text { day) }\end{array}$ & $\begin{array}{l}\text { Joints (arthralgia and arthritis), } \\
\text { lungs (asthma), seizures }\end{array}$ \\
\hline 6 & Zeiss et al. ${ }^{11}$ & 45, F (1974) & 1980 & Prednisone & Joints (arthralgia and arthritis) \\
\hline 7 & Zeiss et al. ${ }^{11}$ & 36, F (1974) & 1980 & Prednisone & $\begin{array}{l}\text { Joints (arthralgia), } \\
\text { neurological (mononeuritis) }\end{array}$ \\
\hline 8 & Zeiss et al. ${ }^{11}$ & 43, F (1976) & 1976 & Antihistamines & Joints (arthralgia and arthritis) \\
\hline 9 & Zeiss et al. ${ }^{11}$ & 46, F (1974) & 1980 & Died of acute pneumonia & $\begin{array}{l}\text { Joints (arthralgia and arthritis), } \\
\text { lungs (asthma), neurological } \\
\text { (depression) }\end{array}$ \\
\hline 10 & Meyrier $^{12}$ & $58, \mathrm{~F}$ & 1984 & Corticosteroids & $\begin{array}{l}\text { Joints (arthralgia), kidneys (renal } \\
\text { venulitis) }\end{array}$ \\
\hline 11 & Sturgess et al. ${ }^{13}$ & $42, \mathrm{~F}$ & 1988 & $\begin{array}{l}\text { Prednisolone }(10-5 \mathrm{mg}) \text { plus azathioprine } \\
(100 \mathrm{mg} / \text { day })\end{array}$ & $\begin{array}{l}\text { Vasculitis affected the femoral, } \\
\text { cystic and renal arteries } \\
\text { Jaccoud's arthritis }\end{array}$ \\
\hline 12 & Palazzo et al..$^{14}$ & & 1993 & $\begin{array}{l}\text { Valve replacement and later a heart } \\
\text { transplant }\end{array}$ & $\begin{array}{l}\text { Jaccoud's hand deformity and } \\
\text { cardiac valve disease }\end{array}$ \\
\hline 13 & Palazzo et al..$^{14}$ & & 1993 & Not known & $\begin{array}{l}\text { Jaccoud's hand deformity and } \\
\text { cardiac valve disease }\end{array}$ \\
\hline 14 & Palazzo et al..$^{14}$ & & 1993 & Not known & $\begin{array}{l}\text { Jaccoud's hand deformity and } \\
\text { cardiac valve disease }\end{array}$ \\
\hline 15 & Wisnieski et al..$^{15}$ & 2 twins & 1994 & Not known & $\begin{array}{l}\text { Kidneys (glomerulonephritis), } \\
\text { lungs (obstructive lung disease), } \\
\text { eyes (ocular inflammation), } \\
\text { joints (arthralgia) }\end{array}$ \\
\hline 16 & Mituiki et al. ${ }^{16}$ & $62, \mathrm{M}$ & 1994 & $\begin{array}{l}\text { No response to corticosteroid treatment. } \\
\text { Died of acute respiratory distress } \\
\text { syndromes }\end{array}$ & $\begin{array}{l}\text { Kidneys (nephrotic } \\
\text { syndrome), eyes (iritis) }\end{array}$ \\
\hline 17 & Wisnieski et al. ${ }^{17}$ & 18 patients & 1995 & & $\begin{array}{l}\text { Angioedema, ocular inflammation, } \\
\text { kidneys (glomerulonephritis), lungs } \\
\text { (obstructive pulmonary disease) }\end{array}$ \\
\hline 18 & Ishikawa et al. ${ }^{18}$ & $33, \mathrm{M}$ & 1997 & Prednisolone (10-5 mg/day) & $\begin{array}{l}\text { Joints (polyarthralgia) Jaccoud's } \\
\text { syndrome }\end{array}$ \\
\hline 19 & Worm et al. ${ }^{7}$ & $43, \mathrm{~F}$ & 1998 & $\begin{array}{l}\text { No response to prednisolone, } \\
\text { dapsone/pentoxifylline, } \\
\text { prednisolone/azathioprine, } \\
\text { cyclosporine, prednisolone/IVIG } \\
\text { Responded to cyclophosphamide- } \\
\text { dexamethasone pulse therapy }\end{array}$ & $\begin{array}{l}\text { Joints (arthritis), } \\
\text { eyes (episcleritis) }\end{array}$ \\
\hline
\end{tabular}


Table 1. Continued from previous page.

\begin{tabular}{|c|c|c|c|c|}
\hline Study & $\begin{array}{l}\text { Age (in years), } \\
\text { sex and date }\end{array}$ & $\begin{array}{c}\text { Case } \\
\text { presentatiom }\end{array}$ & Treatment & Organ involvement \\
\hline 20 Worm et al. $^{7}$ & $45, \mathrm{~F}$ & 1998 & $\begin{array}{l}\text { No response to treatment with } \\
\text { prednisolone, interferon- } \alpha \text {, dapsone/ } \\
\text { pentoxifylline, dapsone/pentoxifylline/ } \\
\text { prednisolone, prednisolone/IVIG } \\
\text { Responded to cyclophosphamide- } \\
\text { dexamethasone pulse therapy }\end{array}$ & $\begin{array}{l}\text { Joints (arthritis), } \\
\text { eyes (conjunctivitis) }\end{array}$ \\
\hline 21 Trendelenburg et al. ${ }^{4}$ & $37, \mathrm{~F}$ & 1999 & $\begin{array}{l}\text { No response to treatment with } \\
\text { hydroxychloroquine, prednisone } \\
\text { alone, plasmapheresis, IVIG } \\
\text { (sandoglobulin } 12 \mathrm{~g} / \text { day for } 5 \text { doses) } \\
\text { Responded to azathioprine } \\
(150 \mathrm{mg} \text { /day) plus prednisone } \\
(60-7.5 \mathrm{mg})\end{array}$ & $\begin{array}{l}\text { Kidney (nephritis), } \\
\text { eyes (conjunctivitis). } \\
\text { Patient subsequently } \\
\text { developed SLE }\end{array}$ \\
\hline 22 Trendelenburg $\mathrm{et} \mathrm{al.}^{4}$ & $43, \mathrm{~F}$ & 1999 & $\begin{array}{l}\text { Azathioprine }(50 \mathrm{mg} \text { /day) plus } \\
\text { prednisone }(50 \mathrm{mg} / \text { day })\end{array}$ & $\begin{array}{l}\text { Eyes (conjunctivitis and episcleritis), } \\
\text { angioedema } \\
\text { Patient subsequently developed SLE }\end{array}$ \\
\hline 23 Houser et al. ${ }^{19}$ & $34, \mathrm{M}$ & 2002 & Valve replacement & $\begin{array}{l}\text { Cardiac valve disease (aortic and } \\
\text { mitral regurgitation) }\end{array}$ \\
\hline 24 Cadnapaphornchai et al. ${ }^{20}$ & $12, \mathrm{~F}$ & 2000 & Dapsone, corticosteroids & $\begin{array}{l}\text { Kidneys (membrano-proliferative } \\
\text { glomerulonephritis), } \\
\text { joints (polyarthritis) }\end{array}$ \\
\hline 25 Grimbert et al. ${ }^{21}$ & $36, \mathrm{~F}$ & 2001 & Corticosteroids, hemodialysis & Kidneys (end-stage renal disease) \\
\hline 26 El Maghraoui et al. ${ }^{22}$ & $41, \mathrm{~F}$ & 2001 & Corticosteroids & Joints (polyarthritis) \\
\hline 27 El Maghraoui et al. ${ }^{22}$ & $39, \mathrm{~F}$ & 2001 & Corticosteroids and cyclophosphamide & $\begin{array}{l}\text { Joints (polyarthritis), } \\
\text { Lungs (cough and dyspnea) }\end{array}$ \\
\hline 28 Chen $_{\text {et }}$ l. $^{23}$ & $29, \mathrm{~F}$ & 2001 & $\begin{array}{l}\text { Prednisone, azathioprine and tolmetin. } \\
\text { Valve replacement }\end{array}$ & $\begin{array}{l}\text { Joints (polyarthritis and } \\
\text { polyarthralgia) } \\
\text { Valvular heart disease } \\
\text { (stenosis and } \\
\text { regurgitation of aortic and } \\
\text { mitral valves) }\end{array}$ \\
\hline 29 Hunt et al..$^{24}$ & $46, \mathrm{~F}$ & 2006 & $\begin{array}{l}\text { Corticosteroids and cyclosporine, } \\
\text { Lung transplantation }\end{array}$ & Lungs (obstructive airways disease) \\
\hline 30 Aydogan et al. ${ }^{25}$ & $44, \mathrm{~F}$ & 2006 & $\begin{array}{l}\text { Prednisolone }(50-80 \mathrm{mg} / \text { day }) \text { plus } \\
\text { azathioprine }(100 \mathrm{mg} / \text { day }) \\
\text { Died of acute respiratory distress }\end{array}$ & $\begin{array}{l}\text { Joints (polyarthritis), } \\
\text { eyes (episcleritis). } \\
\text { Patient fulfilled the ARA } \\
\text { criteria fo SLE }\end{array}$ \\
\hline 31 Staubach-Renz et al. ${ }^{26}$ & $37, \mathrm{~F}$ & 2007 & $\begin{array}{l}\text { No response to antihistamines and } \\
\text { methotrexate/prednisolone } \\
\text { Responded to herapy with IVIG } \\
\text { (intraglobin F and intraglobin } \\
\mathrm{CP} 2 \mathrm{~g} / \mathrm{kg} \text { ) }\end{array}$ & $\begin{array}{l}\text { Joints (polyarthralgia) } \\
\text { Lung (obstructive lung disease) } \\
\text { Eyes (irits) }\end{array}$ \\
\hline 32 Dincy et al. ${ }^{27}$ & $\begin{array}{l}\text { rospective study } \\
68 \text { patients from } \\
\text { outh India from } \\
2003 \text { to } 2004\end{array}$ & 2008 & Not known & $\begin{array}{l}\text { Female preponderance among } \\
\text { patients with HUVS. Systemic } \\
\text { involvement was seen in } 64.3 \% \text { of } \\
\text { of patients with HUVS. Fever, } \\
\text { ANA positivity and SLE were } \\
\text { significantly associated } \\
\text { with HUVS }\end{array}$ \\
\hline 33 Buck et al. ${ }^{28}$ & $34, \mathrm{M}$ & 2012 & $\begin{array}{l}\text { Azathioprine }(150 \mathrm{mg} / \text { day }) \text { and } \\
\text { prednisone, followed by } \\
\text { cyclophosphamide }(250 \mathrm{mg}) \\
\text { and prednisone }\end{array}$ & Myalgia and arthralgia \\
\hline
\end{tabular}

DAH, diffuse alveolar damage; IVIG, intravenous immunoglobulin; SLE, systemic lupus erythematosus; ARA, American College of Rheumatology; HUVS, hypocomplementemic urticarial vasculitis syndrome; ANA, antinuclear antibodies. 
examination showed a diffuse eruption of raised, erythematous lesions which persisted $>24 \mathrm{~h}$ with residual hyperpigmentation (Figures 1-3). Extensive oncohematological, cardiological, dermatological, gastroenterological, infectious and radiological investigations failed to revealed the diagnosis. Laboratory studies showed an increased erythrocyte sedimentation rate, raised level of C-reactive protein, anemia, slight elevation of antinuclear antibodies to 1:80 - without demonstration of double-stranded DNA antibodies complement deficiency and positivity for autoantibodies to C1q. ANCA and immune complexes were not detected. The patient showed resistance to activated protein $\mathrm{C}$ (factor V Leiden). Examination of the urinary sediment revealed isolated glomerular hematuria in the absence of cylinders or proteinuria. Two skin biopsies were performed, at a distance of about 4 months. In both biopsies we observed an intense neutrophilic and eosinophilic inflammatory perivascular infiltrate (Figure 4) with capillaritis (Figure 5). There was edema in the dermis with dilated blood vessels and focal nuclear dust. The overall appearance suggested perivascular and interstitial dermatitis with prominent neutrophils. This pattern is consistent with leukocytoclastic vasculitis. The diagnostic criteria for SLE were not fulfilled and a diagnosis of HUVS was made (Table 2). ${ }^{1}$ The patient was treated unsuccessfully for up to 1 year with several immunosuppressive drugs (cyclosporine 200 $\mathrm{mg}$ /day p.o., cyclophosphamide $100 \mathrm{mg}$ /day p.o., azathioprine $100 \mathrm{mg} /$ day p.o.), immunomodulatory drugs (dapsone $100 \mathrm{mg} /$ day p.o., methotrexate $7.5 \mathrm{mg} /$ week) and antihistamines (anti- $\mathrm{H} 1$ and anti-H2 receptors) associated with variable doses of prednisolone (10-50 $\mathrm{mg} /$ day). During treatment with dapsone (100 mg/day), prednisolone $(12.5 \mathrm{mg} /$ day $)$ and cinarazine the patient was admitted to our hospital with severe dyspnea. Arterial blood-gas analysis showed hypoxia. Laboratory studies revealed a reduction of hemoglobin $(\mathrm{Hb} 7.8$ $\mathrm{mg} / \mathrm{dL}$; normal range $12-14 \mathrm{mg} / \mathrm{dL}$ ). Computed tomography of the chest evidenced the bilateral diffuse basal alveolar filling (Figure 6). The diagnosis of DAH was suggested by the clinical symptoms (dyspnea), the decrease in hemoglobin concentration as well as infiltrates on chest X-ray films and was confirmed by the progressively bloody aspiration and the increase of hemosiderin-laden macrophages in the bronchoalveolar

Table 2. Typical laboratory findings in hypocomplementemic urticarial vasculitis syndrome.

\begin{tabular}{l}
\hline Accelerated ESR \\
\hline Hpocomplementemia with low C1q, C3, C4 \\
\hline C1q antibodies \\
\hline ANA without anti-double-stranded DNA \\
ESR, erythrocyte sedimentation rate; ANA, antinuclear antibodies.
\end{tabular}

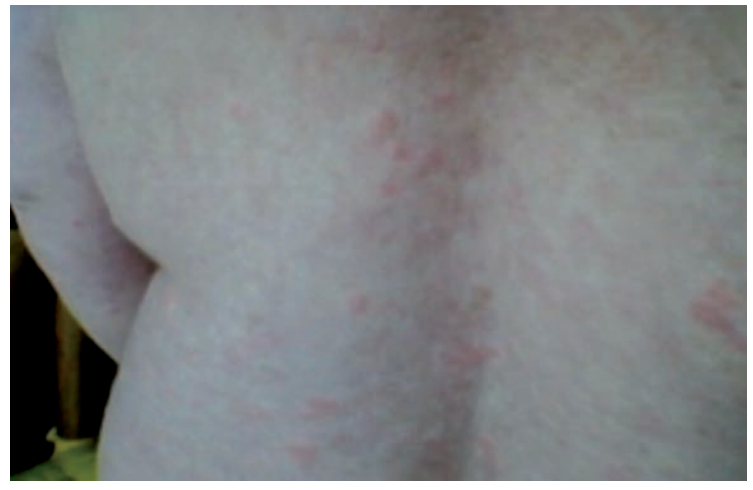

Figure 1. Urticarial vasculitis skin lesions over the patient's back.

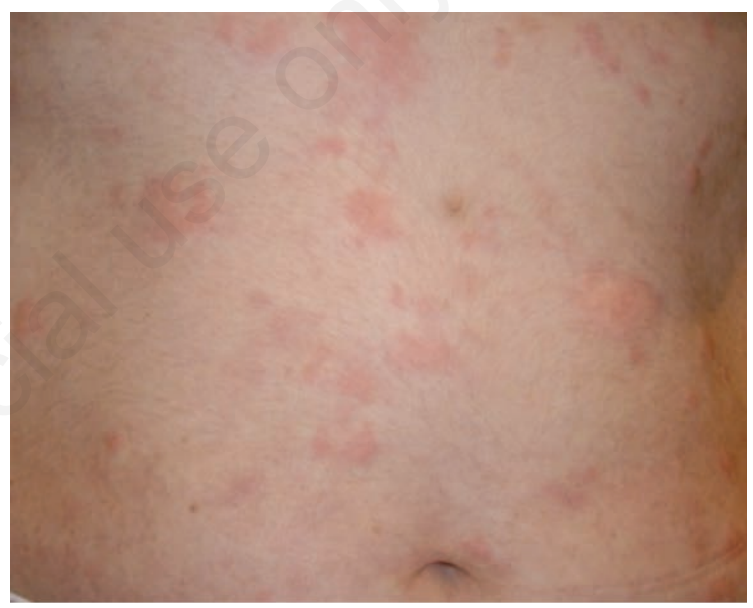

Figure 2. Urticarial vasculitis skin lesions on the patient's abdomen.

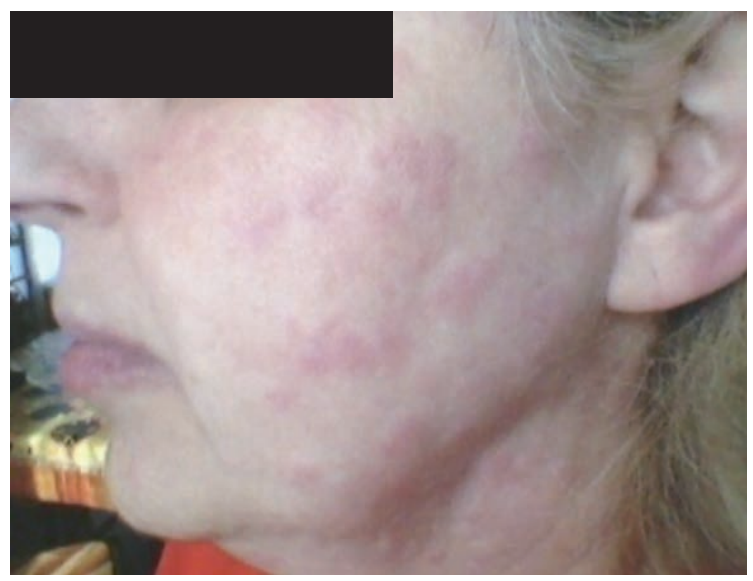

Figure 3. Urticarial vasculitis skin lesions on the patient's face. 
lavage fluid in the absence of macroscopic airway lesions. Cultures for common microbes, Pneumocystis carinii, Aspergillus and Koch's bacillus from the same samples were negative. The intradermal reaction to tuberculosis was negative. The patient was then treated with corticosteroids combined with cyclophosphamide.

Methylprednisolone pulse $(1 \mathrm{~g} /$ day for 3 consecutive days) was given as the initial therapy, followed by cyclophosphamide (100 mg/day) associated with prednisolone ( $1 \mathrm{mg} / \mathrm{kg}$ bw/day p.o.). The patient's health improved progressively and the pulmonary probles resolved completely. The patient is currently receiving 2 $\mathrm{g}$ mycophenolate mofetil combined with $5 \mathrm{mg}$ prednisolone and has been in complete remission for more than 24 months.

\section{Discussion}

In 1971 Agnello et al. ${ }^{8}$ and later McDuffie et al. $(1975)^{9}$ and Oishi (1976) ${ }^{10}$ described some patients with erythema multiforme, C1q precipitins, hypocomplementemia and angioedema and considered that these patients could have a new immune complex syndrome, initially referred to as an unusual SLE-related syndrome. For the first time in 1980 Zeiss et al. ${ }^{11}$ used the term hypocomplementic vasculitic urticarial to define the subgroup of patients who had characteristics similar to those reported by Agnello et al. Currently, HUVS is considered to be an independent immunological disease although differentiation from SLE is sometimes difficult because almost half of all patients with HUVS are positive for antinuclear antibodies and often fulfill the American College of Rheumatology's criteria for SLE. ${ }^{1}$ This is why some authors defined HUVS as an SLE-associated syndrome. ${ }^{25,29}$ Our pa-
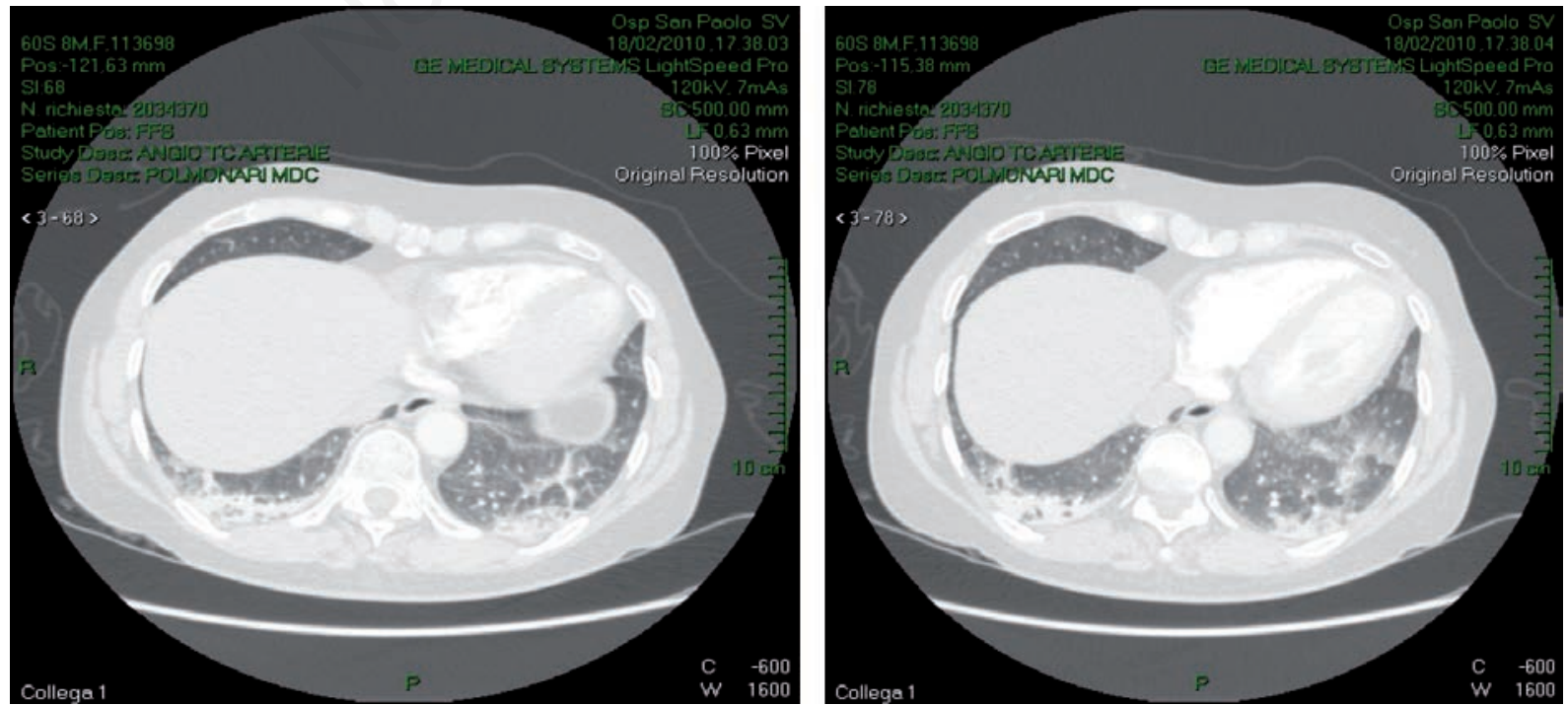

Figure 6. Computed tomography scans of chest showing basal bilateral non-specific alveolar infiltrates. 
tient fulfilled the criteria for HUVS but not for SLE. In fact, he had only two of the 11 SLE criteria.

HUVS is a rare syndrome; its exact incidence and the mechanism(s) underlying the pathogenesis are unknown. ${ }^{2}$ Because of the rarity of this entity the treatment recommendations are based exclusively on reports of single cases or small series. A major problem in treating this disease is the frequent resistance to various therapies including immunosuppressive and immunomodulatory drugs. ${ }^{30}$ For these reasons, the appropriate treatment of HUVS is determined by the severity of the disease and no single therapy is recognized as being highly effective, reliable, safe, convenient and inexpensive. ${ }^{2}$

Table 3. Etiology and histology of diffuse alveolar hemorrhage.

\section{Pulmonary capillaritis}

ANCA-associated granulomatous vasculitis

Microscopic polyangitis

Isolated pulmonary capillaritis

Systemic lupus erythematosus

Rheumatoid arthritis

Mixed connective tissue disorder

Scleroderma

Polymyositis

Primary antiphospholipid antibody syndrome

Henoch-Schonlein purpura

Behcet's syndrome

IgA nephropathy

Idiopathic glomerulonephritis

Acute lung transplant rejection

Idiopathic pulmonary fibrosis

Diphenylhydantoin

Autologous bone marrow transplantation

Myasthenia gravis

Cryoglobulinemia

Ulcerative colitis

Propyl thiouracil

\section{Bland pulmonary hemorrhage}

Idiopathic pulmonary hemosiderosis

Goodpasture's syndrome

Systemic lupus erythematosus

Coagulation disorders

Trimellitic anhydride

Isocyanate exposure

Penicillamine

Amiodarone

Nitrofurantoin

Mitral stenosis

Subacute bacterial endocarditis

Polyglandular autoimmune syndrome

Multiple myeloma

\section{Diffuse alveolar damage}

Bone marrow transplantation

Crack cocaine inhalation

Cytotoxic drug therapy

Systemic lupus erythematosus

Radiation therapy

Acute respiratory distress syndrome

ANCA, anti-neutrophil cytoplasmic antibodies; IgA, immunoglobulin A.
Multiple therapies have been attempted and then is no consensus on a specific treatment for HUVS. Moderate doses of steroids are certainly effective in controlling symptoms, but the adverse effects associated with the long-term use of these drugs make it necessary to evaluate new therapeutic strategies and in particular the use of oral medications to prevent organ allograft rejection and biologics. Cyclosporine has been studied but reports have also suggested that tacrolimus and mycophenolate mofetil are promising therapies. ${ }^{30-32} \mathrm{Cy}-$ clophosphamide-dexamethasone pulse therapy was initially described for the treatment of SLE but has also proven to be effective in Wegener's granulomatosis and in bullous autoimmune dermatoses. Worm et al. reported the beneficial effect of cyclophosphamide-dexamethasone pulse therapy followed by mycophenolate mofetil for the maintenance, ${ }^{33}$ although the published results on this strategy are conflicting.

The fact that the prognosis of HUVS is worse than that of other forms of UV is due to the presence of multi-organ involvement. In particular, lung involvement is associated with shortness of breath, coughing, hemoptysis, pleural effusion, and chronic obstructive pulmonary disease and is the most frequent cause of death among HUVS patients. ${ }^{6}$ In contrast and apparently uniquely, our patient presented with clinicopathological signs of DAH as a manifestation of lung involvement. DAH is usually acute in onset and is generally a condition with high morbidity and mortality. It requires prompt diagnosis and aggressive treatment to improve the survival. A review of the literature shows only a small number of cases of vasculitis associated with DAH and especially with ANCA, Wegener's granulomatosis, Churg-Strauss syndrome and microscopic polyangiitis (Table 3). ${ }^{5}$ The treatment generally includes corticosteroids combined with cyclophosphamide. ${ }^{7}$ To the best of our knowledge, there have been no published cases of HUVS complicated by DAH. In the light of this, the treatment of our patient was largely empirical and her prognosis is unknown. We have reported our clinical experience and views on a possible therapeutic strategy for this previously undescribed combination of conditions. At present, our patient has been in complete remission for more than 24 months.

\section{References}

1. Jannette JC, Falk RJ, Bacon PA, et al. 2012 revised International Chapel Hill Consensus Conference Nomenclature of Vasculitides. Arthr Rheum 2013;65:1-11.

2. Grotz W, Baba HA, Becker JU, Baumgärtel MW. Hypocomplementemic urticarial vasculitis syndrome: an interdisciplinary challenge. Dtsch Arztebl Int 2009; 106:756-63.

3. Vassallo G, Newton RW, Chieng SE, et al. Clinical variability and characteristic autoantibody profile in primary 
C1q complement deficiency. Rheumatology 2007;46: 1612-4

4. Trendelenburg M, Courvoisier S, Späth PJ, et al. Hypocomplementemic urticarial vasculitis or systemic lupus erythematosus?. Am J Kidney Dis 1999;34:745-51.

5. Lara AR, Schwarz MI. Diffuse alveolar haemorrhage. Chest 2010;137:1164-71.

6 . Beasly MB. The pathologist's approach to acute lung injury. Arch Pathol Lab Med 2010;134:719-27.

7. Worm M, Muche M, Schulze P, et al. Hypocomplementaemic urticarial vasculitis: successful treatment with cyclophosphamide-dexamethasone pulse therapy. $\mathrm{Br} \mathrm{J}$ Dermatol 1998;139:704-7.

8. Agnello V, Koffler D, Eisenberg IW, et al. C1q precipitins in the sera of patients with sistemi lupus erythematosus and other hypocomplementemic states: characterization of high and low molecular weight types. J Exp Med 1971;134:228s-241s.

9. McDuffie FC, Sams WM Jr, Maldonado JE, et al. Hypocomplementemia with cutaneous vasculitis and arthritis. Possible immune complex syndrome. Mayo Clin Proc 1973;48:340-8.

10. Oishi M, Takano M, Miyachi K, et al. A case of unusual SLE related syndrome characterized by erythema multiforme, angioneurotic edema, marked hypocomplementemia, and Clq precipitins of the low molecular weight type. Int Arch Allergy Appl Immunol 1976;50: 463-72.

11. Zeiss CR, Burch FX, Marder RJ, et al. Hypocomplementemic vasculitic urticaria syndrome. Am J Med 1999;68:867-75.

12. Meyrier A, Français P, Lesavre P, et al. Hypocomplementemic urticarial vasculitis with glomerulopathy and renal venulitis. Nephrologie 1984;5:1-7.

13. Sturgess AS. Jaccoud's arthritis and panvasculitis in the hypocomplementemic urticarial vasculitis syndrome. J Rheumatol 1988;15:858-61.

14. Palazzo E, Bourgeois P, Meyer O, et al. Hypocomplementemic urticarial vasculitis syndrome, Jaccoud's syndrome, valvulopathy: a new syndromic combination. Rheumatol 1993;20:1236-40.

15. Wisnjeski JJ, Emancipator SN, Korman NJ, et Al. Hypocomplementemic urticarial vasculitis syndrome in identical twins. Arthritis Rheum 199;37:1105-11.

16. Mituiki K, Hirakata H, Oochi N, et al. Nephrotic syndrome due to membranous glomerulopathy in hypocomplementemic urticarial vasculitis syndrome; a case report. Nippon Jinzo Gakkaj Shi 1994;36:863-70.

17. Wisnieski JJ, Baer AN, Christensen J, et al. Hypocomplementemic urticarial vasculitis syndrome. Clinical and serologic findings in 18 patients. Dtsch Arztebl Int 2009;106:756-63.

18. Ishikawa O, Miyachi Y, Watanabe H. Hypocomplementaemic urticarial vasculitis associated with Jaccoud's syndrome. Br J Dermatol 1997;137:804-7.
19. Houser SL, Askenase PW, Palazzo E, Bloch KJ. Valvular heart disease in patients with hypocomplementemic urticarial vasculitis syndrome associated with Jaccoud's arthropathy. Cardiovasc Pathol 2002;11:210-6.

20. Cadnapaphornchai MA, Saulsbury FT, Norwood VF. Hypocomplementemic urticarial vasculitis: report of a pediatric case. Pediatr Nephrol 2000;14:328-31.

21. Grimbert P, Schulte K, Buisson C, et al. Renal transplantation in a patient with hypocomplementemic urticarial vasculitis syndrome. Am J Kidney Dis 2001;37:144-8.

22. El Maghraoui A, Abouzahir A, Mahassine F, et al. McDuffie hypocomplementemic urticarial vasculitis. Two cases and review of the literature. Rev Med Interne 2001;22:70-4.

23. Chen HJ, Bloch KJ. Hypocomplementemic urticarial vasculitis, jaccoud's arthropathy, valvular heart disease, and reversible tracheal stenosis: a surfeit of syndromes. J Rheumatol 2001;28:383-6.

24. Hunt DP. Pulmonary capillaritis and its relationship to development of emphysema in hypocomplementaemic urticarial vasculitis syndrome. Sarcoidosis. Vasc Diffuse Lung Dis 2006;23:70-2.

25. Aydogan K, Karadogan SK, Adim SB, Tunali S. Hypocomplementemic urticarial vasculitis: a rare presentation of systemic lupus erythematosus. Int J Dermatol 2006;45:1057-61.

26. Staubach-Renz P, Von Stebut E, Bräuninger W, et al. Hypocomplementemic urticarial vasculitis syndrome. Successful therapy with intravenous immunoglobulins. Hautarzt 2007;58:693-7.

27. Dincy CV, George R, Jacob M, et al. Clinicopathologic profile of normocomplementemic and hypocomplementemic urticarial vasculitis: a study from South India. J Eur Acad Dermatol Venereol 2008;22:789-94.

28. Buck A, Christensen J, McCarty M. Hypocomplementemic urticarial vasculitis syndrome: a case report and literature review. Clin Aesthet Dermatol 2012;5:36-46.

29. Her MY, Song JY, Kim DY. Hypocomplementemic urticarial vasculitis in systemic lupus erythematosus. J Korean Med Sci 2009;24:184-6.

30. Di Gioacchino M, Di Stefano F, Cavallucci E, et al. Treatment of chronic idiopathic urticaria and positive autologous serum skin test with cyclosporine: clinical and immunological evaluation. Allergy Asthma Proc 2003;24:285-90.

31. Grattan CE, O'Donnell BF, Francis DM, et al. Randomized double-blind study of cyclosporin in chronic 'idiopathic' urticaria. Br J Dermatol 2000;143:365-72.

32. Khan DA. Alternative agents in refractory chronic urticaria: evidence and considerations on their selection and use. J Allergy Clin Immunol Pract 2013;1:433-40.

33. Worm M, Sterry W, Kolde G. Mycophenolate mofetil is effective for maintenance therapy of hypocomplementaemic urticarial vasculitis. Br J Dermatol 2000;143: 1319-59. 